\title{
BRITISH LABOUR AND THE CONFEDERACY
}

\author{
A NOTE ON THE SOUTHERN SYMPATHIES \\ OF SOME BRITISH WORKING CLASS JOURNALS \\ AND LEADERS DURING THE AMERICAN CIVIL WAR

\begin{abstract}
"Then all those, or the descendants of all those, who have aided in the rebellion, by sympathising with the rebels or otherwise, will cry out with an exceeding bitter cry, for its record to be struck from the page of history and its shame to be blotted from the memory of man." Reply to Mr. Lindsay's Speech at Sunderland, August 1864, by S. A. Goddard.
\end{abstract}

There are few legends relating to the history of the Labour Movement which have enjoyed the influence and popularity of the story of how British workmen responded to the American Civil War. Their supposed unanimity in opposition to the Slave Power and their resistance to every ruling class project for intervention on its behalf were thought to be a serviceable example and inspiration, not only by the stalwarts of the International and the Reform League, but by the organisers of the anti-war campaigns of 1878 and after. Even today a writer on "Peaceful Co-existence" finds it an instructive example of the power of the working class in international relations. ${ }^{1}$

Like all good legends this one has endured because it has helped to sustain faith in certain ideals and because it does not fly in the face of the facts, it merely enhances their proportions. Historians have helped to perpetuate this legend and some of them have even improved upon it by ascribing to Karl Marx an important role as organiser of ProFederal sentiment ${ }^{2}$; a role to which he made no claim and to which he has little or no title.

Some thirty years ago Joseph $\mathrm{H}$. Parks made the last serious analysis of British working class opinion and the Civil War. In his article he .did not discuss or question the view that all but an "insignificant minority" of British workmen supported Lincoln and the North. $\mathrm{He}$ assumed that this was the case and set out to show why it was so. ${ }^{3}$ Since that time there has been barely a suggestion that there

1 Rothstein A. Peaceful Co-existence, 1955, p. I4.

${ }^{2}$ Koht, H. The American Spirit in Europe, 1949, p. $\times 38$.

Greenleaf, R. British Labour Against American Slavery, Science \& Society, Vol. XVII, No. I 1953 .

${ }^{3}$ Park, J. H. The English Workingmen and the American Civil War. Vol. 39, I924: Political Science Quarterly. 
were any infuential people in the Labour Movement who stood by the Confederacy, and it has been confidently asserted that the working class press expressed itself vigorously in favour of the Federals. ${ }^{1}$ Yet, in truth, there were a number of eminent Labour leaders whose enmity to the North made them friends to the Confederacy, while workingclass newspapers and journals were, on the whole, hostile to the Federals. (This was unquestionably the case before the Emancipation Proclamation, and even after $186_{3}$ a number of journals continued to lend their support to the cause of Secession). The conventional view that the British working-class "unanimously favoured the cause of the North" can only be explained by the power of the popular legend; a tendency to gloss over the history of the opening years of the Civil War; and the placing of undue reliance upon the reports of middleclass observers, many of whom were eager to persuade themselves and others that democratic enthusiasm was universal among the masses. In the late summer of 1862 , John Bright, who has been justly remembered as the most illustrious of all the English friends of President Lincoln, surveyed the prospects of peace and democracy with much foreboding. Like Richard Cobden he deplored the political inactivity of the working-class, and ascribed it to the fact that "the working-men have no leaders of their own class and they have little faith in any others". ${ }^{2}$ Up to a point Bright was right in his estimate of the situation. The workmen had few leaders who had any established reputation with the general public. But within their own ranks there were to be found many veterans who could still command some attention, while the spread of the principles of the new model unionism among the skilled workers was bringing a new generation of leaders to

1 Dr. Macoby in his English Radicalism (Vol. II, p. 78, note 5) points out that the response of the working-class to the Civil War was more complex than has commonly been supposed. Pratt and Johnson in their English Public Opinion and the American Civil War make incidental reference to one or two Pro-Southern meetings, which were supported by workmen, but no authorities are cited and working-class opinion is generally neglected. Historians who come from below the Mason-Dixon line have tended to minimise the importance of British working-class opinion rather than to point to the conflicts within it. This applies, for instance, to F. W. Owsley's King Cotton Diplomacy. As for the supposed opinions of the working-class press, Max Beloff in History for February 1952 refers without qualification to its "pro-Northern sentiment". (Historical Revision CXVIII). Martin P. Claussen in an article entitled Peace Factors in Anglo-American Relations (The Mississippi Historical Review, Vol. XXVI, No. 4) states that "the anti-war attitude of British Labour was a cardinal point in the struggling labour sheets of the time, such as the Bee-Hive and the Miner and Worker (sic) Advocate; the files of these papers portray a threatening protest against those who would support the Confederacy for a bale of cotton..."

2 John Bright to Richard Cobden, 6th. August I 862. Bright Papers, British Museum: Add. MSS. 43, 384, Folio 296. 
the front. A brief consideration of the opinions held by some of the more prominent of these working-class leaders at the time at which Bright was speaking will show that Confederate sympathies were prevalent among an influential section of them.

When the Civil War began in $186 \mathrm{I}$, the best known British labour leader was the carpenter, George Potter. Potter's fame was based upon his work as the principal organiser and leader of the great struggle of the London building trades for the nine hour day and the right to organise. The strike and lock-out which occured in 1859 attracted nation-wide attention, and was the starting point of a series of disturbances in this industry which continued well into 1862 . One of the results of this agitation was the creation of the London Trades Council in $1860 .{ }^{1}$ In October of the following year the first number of a new Labour newspaper, the Bee-Hive, appeared. This paper was intended to serve as an organ for the Council and Potter established himself as its manager.

Although Potter showed himself to be a reasonably talented strikeleader, he was essentially a man of shallow intellect and equivocal character. He was certainly not qualified to edit the paper, and this job was originally entrusted to a professional journalist, George Troup, with whom Potter had become associated during the builders' struggles. Throughout his life Potter utilised the services of men who had more experience and intellectual self-reliance than he had himself. First Troup, then an old Chartist, Robert Hartwell, then an old Owenite and Christian Socialist, Lloyd Jones, served to provide Potter with a sufficient fund of ideas to sustain him in the course of his career of selfadvancement. There can be little doubt that Potter's opponents were entitled to describe Troup as his "political mentor", and no doubt at all that this man, the first editor of the Bee-Hive, was a passionate and pertinaceous friend of the Southern Confederacy. Even before the Trent Affair had brought Anglo-American relations near to breaking-point, Troup had been using the Bee-Hive as a vehicle for his Southern sympathies. He alleged that secession was a sure way of bringing slavery to an end; and he made great play with the fact that the Negro enjoyed only the rights of a 'second class citizen' in the Northern States. He exploited all the rumours concerning Secretary of State Seward's "foreign war panacea"; he maintained that the Yankees were fighting a war for high tariffs and that it would be perfectly legitimate for Britain to break the blockade of the Southern ports. $^{2}$

1 Harrison, F. Operative Stonemasons Friendly Society, Fortnightly Retum, June 1862.

2 Bee-Hive, 19th. October, 23rd. \& 3oth. November 186r. As quoted in handbill reproduced in Miner and Workman's Advocate, Gth. May 1865. 
The critics of George Potter declared that he was responsible for keeping Troup in office against the wishes of the Bee-Hive's board of directors. There was certainly a widespread belief that Potter had a peculiar responsibility for the paper's policy, and it would seem safe to conclude that he offered no resistance at all to Troup and his policy during I 861 and I 862. The most famous English labour leader of the day was at best a passive accomplice of the Confederate propagandists, and in later years he found it expedient to avoid, rather than to deny, the charges which were brought against him on this account. ${ }^{1}$ However, Potter cannot be made to carry the whole load of responsibility for Troup's exploitation of his editorial position. Formally, the paper was subject to the control of the shareholders exercised through the Board of Directors. Troup could not have lasted long had he been obliged to face determined opposition from this quarter. In fact, Troup was being supported and sustained in his position by other London Trades Unionists besides Potter. They ranged from relatively insignificant people, such as Thomas Vize, a leader of a small painters' society, and a rabid racist, up to the redoubtable T. J. Dunning, the Secretary of the Bookbinders and the "father of London Trades Unionism".

Dunning's experience and accomplishments were likely to give weight to his opinions among 'responsible' and 'respectable' workmen. He had written a book on Trades Unions and Strikes which had been acknowledged with approval by John Stuart Mill. ${ }^{2}$ Dunning had been a Chartist, but in trade union matters he represented that side of the old tradition which - by virtue of its conservative spirit and craft exclusiveness - had the closest affinity to the new model. He was, however, opposed to political action on the part of trade societies ${ }^{3}$ - at least, he was opposed to it when the political cause in question was one which did not find favour with him. A firm friend of the Confederacy, Dunning persuaded his Society to withdraw from the London Trades Council because it had mixed itself up with the Emancipation Society and the friends of Lincoln. As late as 1864 he told the members of his Society that nine out of every ten workmen shared his own Southern sympathies: ${ }^{*}$ sympathies which he did his best to arouse by writing a series of articles in the Bee-Hive on the

1 Odger V. Potter. Decisions of the Committee of Enquiry and comments, Bee-Hive, 24th. June and Ist. July 1865.

2. Dunning T. J. Trades Unions and Strikes: Their Philosophy and Intention, r860.

${ }^{3}$ Dunning T. J. On Politics and Trades Unions, Industrial Magazine No. I, 1862.

4 See pp. 83-85. 
character of the "Yankee". The animus of these articles was not concealed by a judicious show of impartiality. ${ }^{1}$

When the American Civil War began in 1861 there were few men in the London Labour Movement who were as well known as Potter and Dunning. However, no survey of the prominent workmen of the early sixties could neglect John Bedford Leno. Leno had been a shoemaker, he was a veteran of the Chartist agitation, a publicist and a prolific writer of verse. ${ }^{2}$ From the beginning of the Civil War his sympathies were with the South and they were too pronounced to be forgotten or forgiven. When, in April I 865, nominations were being taken for the Permanent Council of the Reform League, "Mr. Leno was opposed on the grounds of his avowed sympathies with the cause of Secession in the Southern States of America" and, apparently for this reason, he was not elected. ${ }^{3}$

It must be stressed that before 1863 Odger, Howell, Cremer and the other men who were associated with the rise of the Junta were not much in evidence. It would, however, be rash to assume that they were all clear-headed supporters of the Northern States in the opening phases of the Civil War. T. G. Facey, a painter who had played a leading part in the builders' strike, and who was to become secretary to the London Committee for the Benefit of Miners, was a Southerner. ${ }^{4}$ George Howell, who boasted that he had always favoured the North, was in fact sounding an uncertain note during the autumn of I 86r. He observed that in America "man is pitted against his brother, without any great principle being involved, except, indeed, that of self-government claimed by the Southerners." He had sufficiently recovered himself in the next passage to add that "the Southerners are only fighting for greater despotic power in relation to slavery", but he was obviously confused by the failure of the North to declare open war upon the "peculiar institution". 5

If many British workmen were doubtful and uncommitted on the American issue during $186 \mathrm{I}-2$ that is scarcely surprising, for the tone of the working-class press bore no resemblance to the statements which have been made about it by historians. Far from being solidly pro-North, it was aggressively Confederate. The Bee-Hive was by no means an exception. Numerous working-class journals called for the raising of the Northern blockade and demanded armed intervention.

1 Dunning T. J. National Character of the Federal States, Bee-Hive, 16th. May 1863 et seq.

2 Leno, J. B. Autobiography, 1892.

${ }^{3}$ Reform League Minutes, 2 ist. April 186 . Howell Collection, Bishopsgate Institute.

4 Howell, G. Reynolds News, 29th. November I 896.

5 Operative Bricklayers Society Circular, October 186 I. 
Reynolds News, as Karl Marx noted, spent "week after week exhausting its horse-powers of foul language in appeals to the working classes to urge the government, in their own interests, to war with the Union". ${ }^{1}$ Reynolds News was reputed to have a circulation of $350,000{ }^{2}$ Lloyds - another mass circulation paper with a workingclass readership - was equally hostile to the Federals. Among papers of this class, only the Weekly Times bestowed any favour upon the North.

Whether judged by the character of its readership or the associations of its founder, Reynolds News deserves to be classed as a workers' paper. It had, however, no close links with the trades unions, nor did it express the opinions of an organised group of working people. The same cannot be said of two other journals which appeared in London at this time and which were run in competition with the Bee-Hive. The first of these was the Working Man, which George Howell had been asked to promote in August 186I. In the event, Howell had nothing to do with this venture, which first saw the light of day only a month before the birth of the Bee-Hive. It was controlled by a committee of workingmen with A. C. Cudden as chairman. ${ }^{3}$ Cudden was a reasonably well-known figure who had developed a theory of surplus value which he expounded in working-class papers. ${ }^{4}$ His colleagues on the board of the Working Man were trades unionists of no great weight or influence, the most interesting figure among them being the shoemaker, Charles Murray, who had a Chartist past and who was soon to be associated with the I.W.M.A. On 5 th. October I86r, this paper carried a leading article which stated: "To a certain extent we can understand that the slaveholders, who, on the faith of the Constitution of the Union, have invested their fortune in human stock, should have some reason to complain if, all of a sudden, they were to be dispossessed of their property, and that they might have a claim to compensation. But if North and South are the willing accomplices of slavery, what are they fighting for - and with which can we sympathise? Are they not both our enemies? Are they not both tyrants of human labour?" The Working Man concluded that there could be no moral objection to raising the blockade and getting cotton for the mills of Lancashire.

1 Marx, K. English Public Opinion. New York Daily Tribune, Ist. February 1862. Reproduced in: The Civil War in the United States by Karl Marx and Frederick Engels, New York, 1937.

2 Jordan, H. D. The Daily and Weekly Press of England in $186 \mathrm{I}$.

The South Atlantic Quarterly, Vol. xxviii.

3 The Working Man, 7 th. September I $86 \mathrm{I}$.

4 Cudden, A. C. Article discussing Theory Of Value, The Co-operator, July 1860. 
The Bee-Hive's second competitor was the British Miner, subsequently known as the Miner, and later still as the Miner and Workman's Advocate. Far from producing a "threatening protest against those who would support the Confederacy", 1 this journal was a consistent apologist for the South right up until the time in 1865 when it was acquired by the Industrial Newspaper Company. John Towers, who was editor of this paper throughout most of the Civil War period, was an unscrupulous adventurer who spent his time attacking Alexander Macdonald, the President of the National Association of Miners. But if Towers, Jike Potter, appeared as an irresponsible critic of the established Union leaders, he could also claim - as could Potter that he helped to.create the organisations whose leaders he attacked , ${ }^{2}$ and he was not without some rank and file supporters. When he was not trying to flay Macdonald, Towers busied himself with discrediting the Emancipation Proclamation and with drawing pictures of idyllic conditions in the old South where contented Negro slaves laboured for their philanthropic masters. ${ }^{3}$

A reproach which can be justly levelled against much that has been written about the Labour Movement in the eighteen-sixties is that it concentrates attention upon London to the exclusion of the Provinces. However, an examination of provincial papers suggests that the "Copperhead" element was not confined to the metropolis.

The most important working-class paper which was published outside London was the Glasgow Sentinel. It was the proud boast of the Sentinel that it was the only acknowledged organ of the working classes in Scotland. This claim cannot be lightly dismissed. The Sentinel's coverage of news relating to trades unions was excellent; it numbered old Owenites such as Robert Buchanan and Lloyd Jones among its contributors and, from 1863 , it was edited by the father of the Scottish Labour Movement, Alexander Campbell.

Campbell has yet to find a biographer, and in his own lifetime his fame probably did not spread far beyond working-class circles; but the most cursory account of this picturesque and charming figure cannot fail to suggest that workmen would attach the greatest weight

1. Claussen M. P., Peace Factors in Anglo-American Relations. Mississippi Historical Review, Vol. XXIV, No. 4.

2 He was Secretary to the Conference which launched the National Association of Miners in 1863 . Miners' National Conference at Leeds. The Miner and Workman's Advocate, 14 th November 1863 .

3 The Position in America. The British Miner (Subsequently The Miner and then Miner and Workman's Advocate), 28th. February I 863. 
and importance to his opinions and to those of any organisation or journal with which he was publicly associated. 1

He was born towards the end of the eighteenth century in the heart of the "Campbell country", at the point of Skipness on the shores of Kintyre. He was a carpenter by trade, but soon rose to be a master cabinetmaker. In $\mathbf{1} 822$ he was Treasurer of a Co-operative Society in Bridgetown. A few years later he was one of the most active members of the Owenite Colony at Orbiston, but he allowed himself to be made liable for the colony's debts, and, as a consequence, served a term of imprisonment. Campbell's sublime faith in the principles of Robert Owen was undisturbed by this experience, but it may have caused him to re-examine the financial basis of the Co-operative movement, for it was Campbell who first recommended the principle of dividing profits on purchases, which was so successfully applied by the Rochdale Pioneers.

During the agitation for the "Great" Reform Bill, Campbell was at work in Glasgow, where he strove to unite all classes of Reformers. At the beginning of January I $_{3}$ I a public dinner was held at which a factory worker presided, and which was attended by Whigs as well as middle-class radicals. Campbell's Trades Committee had been responsible for organising this impressive and memorable affair and Campbell was already organising workmen into a political force through his Herald to the Trades Advocate. However, the class alliance did not last long, and Campbell was soon back in jail for offences against the Stamp Acts.

The struggle was taken up again at the level of trades unionism. Late in I 83 I Campbell established a consolidated union, divided into trades sections, which was known as 'The General Union of Glasgow'. Like the rest of these experiments in general union, this proved to be an ephemeral organisation and by 1834 Campbell was occupying no more than the prosaic post of secretary to the Glasgow Carpenters' Society.

As one of Owen's first Social Missionaries, Campbell travelled widely. He assisted striking potters in Staffordshire in 1836 ; helped to spread co-operative ideas and organisation in Oxford; and was nominated workingman's candidate for Stockport in 1847 . Next year

1 Marwick, W. H., Scottish Social Pioneers, VI, The Scottish Educational Journal, 26th. February 1932. The Campbell Testimonial, The Glasgow Sentinel, 6th. July and 13 th. September 1862. Obituary notices of Robert Buchanan (Sentinel, 17th. March I 866 and of Campbell (Sentinel, I 9th. February I870). Campbell in reminiscences of Sentinel readers. Sentinel, 3oth. August \& I5th. November 1862. Campbell's testimony before the Parliamentary Committee on the Master and Workman Act, (Sentinel, 3oth. June 1866). G. J. Holyoake on relation between Campbell, Howarth and the Rochdale Pioneers, The Social Economist, 1st. November 1863. 
he was in London, where he collaborated with his friend Buchanan in establishing The Spirit of the Age and, later, The Spirit of the Times. This collaboration was continued on the Sentinel, which Buchanan began to edit shortly after its foundation at the end of 185 I. Campbell became the industrial correspondent in 1858 . It seems likely that he also became secretary of the Glasgow Trades Council in the same year. He certainly led the Council's campaign against the Master and Servant Acts in the course of which what has sometimes been regarded as the first Trades Union Congress was held.

Here we have a figure of major importance. What was the line taken by the paper with which he was so closely associated in relation to the American Civil War? "It is quite certain," declared the Sentinel of i 7 th. May 1 862, "that when the moment for action arrives, our own government must energetically second the efforts of France to stay this bootless strife." By July, the readers of the paper were being given the impression that these sentiments were spreading among workmen: "The idle artisans of the English towns begin to regard the American conflict less in the light of a misfortune to an allied people than as a blameable struggle for supremacy between the two factions of the States in which the North especially seeks to gratify its desire for territorial aggrandisement". 1 Emancipation was denounced as "petty and abortive spite", ${ }^{2}$ and by 1863 (when Campbell took over the editorship) the North was being advised to abandon the conflict and content itself with a good boundary line.

The Sentinel was owned by Robert Buchanan until he went bankrupt in 1860 . It then passed into the hands of James Watts, a well-known Scottish newspaper proprietor. ${ }^{3}$ Since neither Campbell nor Buchanan had financial control of the paper during the Civil War, some doubt may exist as to how far they were responsible for its American policy. But it is highly improbable that Campbell would have been made editor if he had been a friend to the Federals. Only a few months before Campbell acquired the editorial post, his old associate, Lloyd Jones, was obliged to retire from the staff because he declined to advocate the Confederates' cause. ${ }^{4}$ The experience of George Julian Harney, who was deprived of his editorial control of the Jersey Independent provides another instance of how sincere sympathisers

1 This was a reference to a workers' meeting held in Stockport. However, The Stockport Advertiser, 27th. June 1862 , reported strong opposition from the floor. - The Glasgow Sentinel, $s$ th. July I 862.

2 Ibid. I Ith. October 1862.

${ }^{3}$ Cowan, R. W.M., The Newspaper in Scotland.

4 Ludlow, J. M., Some of the Christian Socialists of 1848 and the following years. Economic Review, January 1894. The Glasgow Sentinel, 25th. July I 868. 
with the Northern States were called upon to make sacrifices for their convictions when the papers they worked for were owned by supporters of the Confederacy. ${ }^{1}$

The best pointer to Alexander Campbell's sympathies in the American quarrel is probably the London Letters which were written by his friend Buchanan. The recurrent theme in these Letters was the impossibility of subduing the Southern States. Like the well-known radical controversialist, William MacCall, ${ }^{2}$ Buchanan laid stress on 'Garrisonian' arguments against the Union, suggesting that Secession would make emancipation of the slaves inevitable. ${ }^{3}$

The line on the American conflict adopted by the only other paper in Glasgow with any claim to be regarded as a working-class organ, was equally at variance with received opinions on how British workingclass journalism responded to the Civil War. The Glasgow Gazette was edited, published and printed by Peter Mackenzie, an old warrior who had seen better days. For more than thirty years he had challenged Alexander Campbell for the allegiance of the working men of Glasgow. Before 1832 he had been a physical force reformer, and Campbell's supporters alleged that the fierce language which he used in The Loyal Reformer's Gazette had been responsible for throwing the authorities into such a panic that they clamped down indiscriminately on the entire radical press.

Peter Mackenzie's comments on the Civil War make strange reading if his democratic and revolutionary record is borne in mind. He declared that up until the time of Bull Run his sympathies lay with the North. For some months after that memorable and humiliating disaster, his opinions went through a series of violent but inconclusive alternations: now meditating upon the just but terrible fate that would befall the "scoundrels of New York" if a British regiment entered that city, now contemplating the anguish of the slave-holder deservedly perishing in the wreck of his own destruction. ${ }^{4}$ By September of I 862 , he had finally reached the remarkable conclusion that "Democracy has been at the root of the whole of the present difficulties in America". ${ }^{5}$ Secession was part of America's "inevitable destiny", the interests of Britain and the world required that this fact should be recognised and the war brought to a speedy conclusion. As for

1 The Jersey Independent and Daily Telegraph, 29th. November 1862.

2 His journal, The Propagandist, was favourable to the Confederacy.

${ }^{3}$ London Letters, Glasgow Sentinel, I 863-64. Obituary of Robert Buchanan, (Sentinel, I 7 th. March I 866 ).

4 Glasgow Gazette, 25th. January \& 28th. June 1862.

5 Ibid., 6th. September 1862. 
Confederate resistance - "There is nothing more magnificent in the history of man". ${ }^{1}$

The Glasgow Gazette expired before the Civil War was over. As Mackenzie sadly observed: 'My once fearless 'weekly' - my wellloved Old Loyal Reformer's Gazette, was compelled, like the brave Southern Confederacy, to yield to numbers." 2 Thus, with this bizarre comparison, the old rebel who did so much to keep alive the memory of Thomas Muir and other martyrs for British liberty, saluted the Slave Power.

Working-class papers in Lancashire and the north of England were few and far between. Sometimes a new venture would perish after a few issues; in other cases files of such papers have been destroyed and no further copies have been traced. But the Manchester Weekly Budget, which was supposed to enjoy "an immense circulation among the factory operatives of the North", 3 was one of the most violently "Confederate" papers in the country. One extract, taken from an issue of this journal, will more than suffice as an illustration of its style: "Bloody as the war is and inflictive of untold wrongs and mobberies upon virtue and innocence, it will not have been without its compensation in ridding the world, by the bullets of the Southerners, of the human scum, poured out of every country under heaven, which forms the ruck of the mob armies of the tyrant States." 4

The Weekly Budget may have had small title to the respect of the factory operatives who read it, but the same cannot be said of the Oldham Standard. This paper was controlled by Joseph Rayner Stephens, whose boundless courage in the fight for the Factory Acts made his name familiar to workers throughout the cotton districts. ${ }^{5}$ On the whole, Stephens argued that the rights and wrongs of the American quarrel were no concern of British workmen; but, as the war progressed, his hostility to Abraham Lincoln and the Union became increasingly marked. At first he was satisfied to denounce as a "ridiculous and contemptible imposture" the attempt to attribute to Lancashire working people a sympathetic regard for the North; workers saw the Civil War as "a subject which they were not called upon to discuss." 6

But a few months later, in the Oldham Standard of ${ }_{13}$ th. June 1863 , he was anxious to report a growth of Southern sympathies in

1 Ibid., 9th. April r 864.

2 Mackenzic, P.: Reminiscences of Glasgow and the West of Scotland, I 866.

3 The Saturday Review, 3 Ist. August 186 I.

4 The Weekly Budget, 22 November 1862.

${ }^{5}$ Holyoake, J. G. Life of J. R. Stephens (1872?).

6 The Oldham Standard, 3 rd. January 1863. 
Oldham and was actively encouraging them himself when he wrote on the previous week's issue of the paper: "The North and their abettors are well aware that the independence of the South means the abolition of slavery; but that the maintenance of the Union signifies its perpetuation..."

In general the "Copperheads" within the British working-class preferred to express their opinions in the press rather than to test the feeling of public meetings. There were exceptions to this rule. In Lancashire, Mortimer Grimshaw, who had been a member of the Labour Parliament of $18 ; 4,{ }^{1}$ did his best to interest the cotton operatives in armed intervention. By all accounts, Grimshaw was a most unsavoury character and, with the exception of the Index, the organ of the Confederate agent, Henry Hotze, ${ }^{2}$ no one had a good word to say for him. ${ }^{3}$ Charles Dickens used Grimshaw as the model for the unfavourable portrait of a trade union leader which appeared in Hard Times and the Lancashire workers displayed as great a contempt for him as did the famous novelist. Thus, when Grimshaw and a few of his friends called a meeting in the market-place at Blackburn with the object of petitioning Parliament to adopt the motion of Mr. John Turner Hopwood M.P. for mediation between the Northern and Southern States of America, "in order to bring the fratricidal war to an end", they met with overwhelming defeat. Four to five thousand workers attended and only twelve were found to vote for Grimshaw's resolution. Under the leadership of Crossley, the Secretary of the Blackburn Weavers' Association, the meeting carried a vote of no confidence in Grimshaw and declared itself in favour of the policies of Abraham Lincoln and the Union Government. ${ }^{4}$

It would, however, be a mistake to read into the ineptitude of one demagogue the insignificance of the entire Copperhead group; just as it would be wrong to suppose that Crossley and other Union officials were spending their time counteracting Southern sympathies and rousing workmen for the North. A few days later an indoor meeting was held in Blackburn, also largely attended by workmen, at which a majority was found for a resolution calling for British initiative in setting up a European alliance to end the American War. ${ }^{5}$ Trades Union leaders, in Lancashire and elsewhere, showed great reluctance

1 Saville, J., Ernest Jones: Chartist. I952. Appendix IV, p. 272.

2 Jameson, J. F., The London Expenditure of the Confederate Secret Service, The American Historical Review, July 1930.

3 The Index, 8th. December I 864.

4 Mediation in the American Quarrel: Meeting of Operatives. Blackburn Patriot, sth. July I 862.

5 Ibid., 9th. August 1862. 
- when talking in their official capacity - to discuss foreign questions. ${ }^{1}$ When they referred to them at all, it was generally to dismiss them as Tom Banks of the Preston Spinners and Minders Association did when he declared that "the serfs of Russia and the slaves of America are better treated than the factory operatives, either on the Moor or in the stoneyard." 2 The organised workers of the cotton towns did not demand armed intervention; for the most part they did not show any official concern with the question. What they asked of the Government was that conditions of relief should be made more equitable, that the labour tests should be abolished and that a stimulus should be provided for the growth of cotton in the colonies. Certain attempts were made by Confederate sympathisers to exploit discontent with the middleclass relief committees in the interests of the South, but the attitude of the industrial and social organisations towards the Civil War remained, officially and formally, non-commital. A Manchester journal, The Co-operator, was taking up a representative position when it stated that: "After due reflection and consideration, we think it prudent to withhold 'Young England's' promised articles on this controversial subject (the Civil War); not alone through fear of causing a schism in the co-operative camp, or from an underestimate of the importance of the subject to every Englishman, and especially to Co-operators, but because the topic would be foreign to the object of The Co-operator...." 3 Similarly, such references as there were to American affairs in the trades union circulars of the day tended to be oblique. Thus, a branch of the Stonemasons' Society, in discussing the conduct of the master builders in London, remarked that the British Government's handling of the "Yankee" during the Trent affair showed the value of a firm stand against wrongdoers. ${ }^{4}$ In October 1862, Mr. Gladstone was persuaded that "the people of England are

1 The political quality of the stoicism displayed by the Lancashire operatives - particularly in the early years of the Civil War - could be subject to more than one interpretation. Thus, while the National Review (January 1863 ) found that the absence of any agitation for intervention in America signified that the operatives were "readier to endure wrong

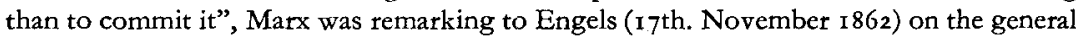
passivity and lack of initiative on the part of the operatives, their "sheep's attitude", their Christian Slave nature. Such observations - although directed to working-class response to conditions of relief - raise the question of how far the workers' silence on the American War was informed by political understanding and how far Marx was intending to revise his own earlier estimates (New York Daily Tribune, Ist. February I 862) and on "the indestructible excellence of the English popular masses" (Die Presse, 2 February 1 862).

2 The Labour Test, The Preston \& County Advertiser, 2nd. August I 862.

3 The Co-operator: A Record of Co-operative Progress: Conducted Exclusively by Working Men", June $\mathrm{I}_{86}$.

4 Circulars and monthly reports of the Engineers, Carpenters, Bricklayers, Stonemasons and Bookbinders have been examined. 
being rapidly drawn into Southern sympathies". ${ }^{1}$ Consequently, he was preparing a Memorandum for the Cabinet on the possibilities of joint intervention in the Civil War on the basis of Secession being acknowledged. ${ }^{2}$ During the next six months, the position, as far as the working-class was concerned, was rapidly transformed. By March I 863 The Times was accepting it as quite natural that the majority of workmen should favour the Federals, and few questioned where their sympathies lay. ${ }^{3}$ The number of public meetings at which workers endorsed resolutions applauding Lincoln and the Union provided overwhelming evidence of how matters stood, ${ }^{4}$ - although some allowance must be made here for the fact that many of these meetings were arranged by middle-class radicals or Federal agents. ${ }^{5}$ (The agents of the Confederacy appear to have devoted most of their money and attention to the press). ${ }^{6}$

The timing and extent of this demonstration of working-class sympathy with the North might suggest that the early Southernism of Labour newspapers was merely the result of confusion respecting the aims of the Federals; a confusion which was dispelled by the Emancipation Proclamation. It might be maintained that diplomatic blunders by Seward, rumours of his "foreign war panacea" and indignation at the "Stone fleet", made it difficult for the best disposed of journalists to espouse the Northern cause; while Bull Run and other examples of military ineptitude encouraged the view that the conquest of the South was an impossibility. So long as the North was not avowedly fighting against slavery, it might plausibly be maintained that the Confederates were fighting for their independence.

This interpretation of the origins of Southern sympathies is one which it would be foolish to discount. It should be remembered that even among those who were from the outset fundamentally and profoundedly opposed to the Slave Power, there was great disillusionment arising from the corruption and incompetence exhibited by the Federals. In the early days of the War, Cobden had his doubts and hesitations, while Engels wrote: "... for the present moment I must say that I cannot work up any enthusiasm for a people which on such a colossal issue allows itself to be continually beaten by a fourth of its own population, and which after eighteen months of war has

1 Guedella, P., Gladstone and Palmerston (1928. p. 245).

2 Gladstone's Memorandum of 25 th. October I 862. ibid.

3 The Times, 28th. March 1863.

4 Adams, E. D., Great Britain and the American Civil War, Chapter XVI, p. 223.

${ }^{5}$ F. H. Morse to Secretary of State Seward, 17 th. January 1863 . Despatch No. II, Consular Letters, London, Vol. 3 I, Department of State Records. Cited by Claussen, Peace Factors...

6 Jameson, J. F., op. cit. 
achieved nothing more than the discovery that all its generals are idiots and all its officials rascals and traitors". 1

However, the political and military contingencies which characterised a particular period of the war cannot be regarded as a wholly satisfactory explanation of southern sympathies in the Labour Movement. The general tone of the working-class press was still pro-Southern after $186_{3}$, even if the early unanimity and intense bitterness was no longer evident. ${ }^{2}$ Clearly, one must probe deeper to discover the raison d'etre for Southern sympathies.

The division of opinion within the Labour Movement in relation to the Civil War in America followed along the same lines as the general division of opinion in the country at large. It was a class question. John Morley, writing in the Fortnightly Review in October 1870, recalled that: "In the American Civil War partisanship with the sides there was the veil of a kind of Civil War here. An unspoken instinct revealed to mutually hostile classes in England that their battle also was being fought in the contest between the free North and the slaveholding South..." In fact, the instinct which led workmen to fight their battles vicariously in other countries was not so "unspoken" as Morley suggested. Some of them publicly expressed the opinion that the social conflict in England was so closely bound up with the military conflict in America that in their victory the Federals were sure to overthrow more than their enemies.

Not all workmen took up the same position in regard to the "mutually hostile classes" - manufacturers and landed oligarchy - mentioned by Morley. The veterans of the class struggles of the first half of the nineteenth century were, many of them, still completely unreconciled to capitalism, and the hostility which they felt for the manufacturers and mill-owners took its point of departure in the old, primitive opposition to modern industry as such, rather than in visions of constituting modern industry on a co-operative instead of a competitive basis. Working-class leaders, journalists and advisers who still

1 F. Engels to K. Marx, 5 th. November 1862 (See also Engels to Marx, I 5 th. November I 862). The Civil War in the United States by Marx and Engels, p. 299. 1937.

2 The Working Man repudiated its early Southernism by the middle of 1862 . The BeeHive's editorial policy - as will be shown - was subject to more than one change. These two journals were indisputably "working-class". Reynolds, The Sentinel, The Miner and Workman's Advocate and the Glasgow Gazette were all consistently hostile to the North throughout the War and, whether judged by their content or the associations of their editors or proprietors, should surely be described as "working-class". Whether a proFederal journal such as the Reformer and South Wales Times had less claim to be described as a "workers' paper" than the Weekly Budget is a nice question. However, it seems most improbable that a sufficient number of these marginal cases could be found to alter materially the general judgment respecting the Confederate proclivities of the workers' press. 
thought of the industrial capitalist as the main enemy, or who treated the propertied classes with an impartial and indiscriminate hostility, tended to favour the Confederacy, or took up a "neutralist" position which, in practice, favoured the South. On the other hand, the minority of Chartists who advanced towards a socialist standpoint, together with the new model unionists who were out to secure themselves a "stake in the country", were necessarily committed to modern industry and to democratic liberty and therefore tended to support the North. Such men had no time for Confederate sympathisers who followed Charles Kingsley in sentimentalising about the claims of "Wessex" as against those of Lancashire.

The relation between the American War and domestic political conflict was recognised on all sides. The trials of American democracy became a test of the viability of the creed of the English radicals. The name of Bright was everywhere linked with that of Lincoln, so that there was nothing unusual in a representative of the English oligarchy remarking: "If I had my way, I would blow President Lincoln from a mortar with a bombshell, and if there wasn't wadding enough I'd ram John Bright down in after him". 1 Those labour leaders and their advisers who remained unreconciled to capitalism, and who shared vivid recollections of the competition of Bright and Cobden with the Chartist and factory reform movements, were the mainstay of the Confederacy in the Labour Movement. The perfidy of these 'umble and 'omely manufacturers remained an idee fixe with many a veteran. Tory Democrats, such as the Reverends Stephens, Verity and Kingsley; political militants and soured Chartists who belonged to a bygone era, such as Reynolds and Mackenzie, were placed among those who...

"In slavish contradiction all their private judgment smother And blindly take one course because John Bright prefers another"

To link Bright's name with the cause of democracy in America was particularly characteristic of the "Labour" press. The Weekly Budget, which was fond of extolling Richard Oastler as the best type of workman's friend, pronounced itself in favour of recognising the Confederacy, and added: "We have no desire to see the government of this country Bright-ridden". ${ }^{2}$ The Oldham Standard saw Bright's hand in every demonstration of working-class support for the North, and it declared that Bright was only interested in getting up these demonstrations so as to drown the people's voice with a "wild shriek of republican vengeance and terror."

1 Solly, H., These Eighty Years, Vol. $\amalg$, I 893. p. 247.

2 The Weekly Budget, 22 November 1862. 
There is much interesting support for the view that Southern sympathies in the Labour Movement had their sources in the long memories of old Chartists and Tory Democrats. For example, one can sometimes discern an association between the old agrarian idealism and the cry for British intervention in the Civil War. "Cotton, the great seducer that has deluded our active population from the labours of the fields, where they were enjoying pure air, and where, if they did not accumulate great fortunes for the high priests of Mammon, they were, at least creating an abundance of a sounder wealth. Why should we starve any longer, since, unfortunately, cotton has become our bread? Let us then insist on the raising of this blockade...". 1

This language, like that of J. R. Stephens at Oldham, which was reputed to be "the most pro-Southern town in England," is reminiscent of the far-off days of William Cobbett.

The Confederate sympathisers did not attempt to defend slavery, although they occasionally made out that it was not so terrible as it was supposed to be. Their argument was that the Wilberforces of the North were every bit as blameworthy morally as the slave-owner of the South. England was under no moral obligation to hold the ring while Americans decided whether the negro was to be treated as a leper or a chattel. One workman expressed the same attitude in yet more general terms:

"Must not our Southern Lords be fools

To buy their slaves, when they're so plenty;

When stealing land by laws and rules,

And keeping poor folks' stomachs empty,

Would give them wages slaves for naught,

Who'd beg to have their labour bought." 2

In short, there were workmen who saw no great principle at stake in the Civil War, and consequently felt free to advocate the raising of the blockade or some other measure which would in practice have served the interests of the Confederacy. It was natural that such men should have found no great difficulty in persuading themselves that the Confederates were, after all, fighting for their independence and on that account entitled to the support which British workers traditionally accorded to subject peoples. If Bright and Cobden supported the Yankees and the cause of the "all-mighty dollar" this was probably but another instance of their detestable pacificism and indifference to aggression. Men with the background of Mortimer Grimshaw knew very well what to think of the Peace Society and its fellow-travellers!

There were Southern sympathisers in the Labour Movement who

1 The Working Man, sth. October $x 86 \mathrm{r}$.

2 Burgess, E., Wages Slavery, reprinted in: The Republican, I5th. May I87I. 
were neither old Tory Democrats nor soured Chartists. Indeed, George Troup, the first editor of the Bee-Hive, and the most influential friend of the Confederates in the working-class press, belonged in neither or these categories. Yet his "Southernism" was inspired by considerations which were consistent with the ones that have been described. He hated the North, and detested Bright and Cobden, but not because he set store by precapitalist relationships, but because he saw beyond the cosmopolitan and competitive capitalism of his day to a new era in which a British Imperial Federation would be in rivalry with the United States.

George Troup, the son of a master cabinetmaker, was born in I8I I in Stonehaven, the county town of Kincardinshire in Scotland. $\mathrm{He}$ first distinguished himself as an anti-slavery agitator and it was, apparently, his activities in this field which led him to catch the eye of Tait's Edinburgh Magazine. He embarked on his career as a journalist and by 1847 he had edited important papers in Liverpool, Glasgow and Belfast. This association with the great centres of British shipbuilding was, no doubt, of great importance for Troup's political development. He enjoyed the highest confidence of the merchants and ship-owners of Glasgow. They took steps to keep him in the editorial chair of the North British Daily Mail when its proprietor, the great ironmaster Alexander Alison, was faced with ruin as a result of the financial crisis of $1847 .{ }^{1}$ The British shipping industry was particularly sensitive to American competition during the period prior to the Civil War. A large part of the Atlantic carrying trade was in the hands of the Americans, and there was much petulant criticism on the Clyde of the subsidies given by the government of the United States to its fleet. In Scotland there was a growing disposition in favour of a return to protection. Thus, Glasgow and Liverpool began to be associated with a new anti-Mancunian school of Liberalism. Troup associated himself with this development and began to express a marked antipathy to Sir Robert Peel, to Free Trade and to the United States of America.

In I840 Troup had written a pamphlet entitled the "Anti-Christian Character of the Corn Laws", but by 18,2 he had put this sort of thing behind him and was helping to form a remarkable organisation known as "The West of Scotland Reciprocity and Industrial Association". The Association was an anticipation of Liberal Unionism, since its programme was nothing less than imperial preference, and insistence upon

1 Troup, G. E., George Troup: Journalist, 188r.

Marwick, W. H., The Scottish Educational Journal, I6th. March 1934. (Neither of these works describes Troup's association with the Bee-Hive. For this purpose it is necessary to consult the records of the Trades Newspaper Company and the files of the paper). 
the principle that no concession should be granted to foreign states unless Britain received some trading advantage in return. As a member of this body, Troup received the "kind regards" of Disraeli, and was in touch with W. S. Lindsay M. P., who was subsequently to become one of the most famous of the English friends of the Confederacy. ${ }^{1}$

When George Potter first came into association with Troup, he had returned to Tait's Magazine in Edinburgh. In the pages of the journal he found room for a word in support of the London builders, but most of his powder and shot was reserved for attacks on the United States - attacks which he coupled with observations respecting the manifest destiny of Britain in Asia and Africa. We ought, he argued, to get our cotton from the Empire. The Colonists were our friends; the Americans viewed us with suspicion. The great majority of Americans were attached to slavery, and they regarded Britain as a vast Emancipation Society bent on crusading for freedom in the Carolinas. We had much better things to do. We bought far too much from the United States. The Americans spent the bullion which they earned here in France and Switzerland. The only answer was Empire Free Trade. ${ }^{2}$

It seems likely that Troup's motives for favouring the Confederacy were religious as well as imperialist. He was a devout evangelical and a member of the Free Church of Scotland. At the time of its foundation that Church had been faced with the most serious financial problems and, to help surmount them, a mission was dispatched to the United States in 1844 . In its appeal for funds, this mission met with a much better response in the Southern than it did in the Northern States. When this became known, voices were raised in Scotland against accepting "bloodstained slave money". The Anti-Slavery Societies were not slow to attack the Free Church, so that by 1846 it was having to face "a full-scale onslaught" from the abolitionists and their friends. ${ }^{3}$ Thus, it seems highly probable that long before the outbreak of the Civil War, Troup's religious affiliations had brought him into conflict with the abolitionists and led him into defending the munificent Southerners.

If Troup was in sympathy with the Confederacy for reasons which were far removed from the main stream of working-class tradition and experience, that did not make him any less formidable as editor of the most representative workers' paper of the day. So long as the official organ of the London Trades Councils was in his hands, it was bound

1 Troup, G. E. op. cit.

2 Tait's Edinburgh Magazine, August 1859.

3 Shepperson, G., The Free Church of Scotland and the South, Journal of Southern History, November I95I. 
be difficult and dangerous to organise any demonstration in London in support of the North. The Positivists, particularly Professor E. S. Beesly, together with one or two middle-class radicals, had been trying for some time to get the Trades Council to engage in political action, ${ }^{\mathbf{1}}$ but they scored no real success until after Troup's removal from the editorial chair of the Bee-Hive.

The election, by the shareholders of the Bee-Hive, of a new board of directors for the paper co-incided with the October Emancipation Proclamation. This probably produced a majority on the board which would not tolerate Troup's Southern sympathies. However, there was a complicating factor in the shape of an unpaid mortgage on the property of the paper, and Confederate agents in London were trying to exploit this in order to retain control. George Odger went and laid the facts of the case before Basley Potter M. P. and other friends of the North. According to R. J. Hinton's rather garbled account of the matter, "the money was found for $\mathrm{Mr}$. Odger to take up the mortgage with, and at the business meeting called to consummate the bargain with the Confederate agents, Mr. Odger announced that he had the controlling position." 3

Thus, by the beginning of I 863 , Troup was no longer editor of the Bee-Hive. His grip on the paper had not been entirely broken, but for a year its editorial columns were filled with pro-Federal productions from the pens of Beesly, Robert Hartwell and others. The tone of the Bee-Hive's far less influential contemporary, the Workingman, had already undergone a similar change, but the rest of the Labour press remained bostile to the North. ${ }^{4}$

There were still serious obstacles in the way of a decisive demonstration of working-class opinion on the War. Professor Beesly and Frederic Harrison had for many years been hoping for a political

1 Minutes of the London Trades Council, r 7 th. December $186 \mathrm{r}-$ (Beesly and Stansfeld to discuss "the steps likely to be taken with reference to politics") 2oth. May I862.

(Frederic Harrison and the development of political association with Italian workers).

Annual Report of the London Trades Council, 1862. (Congreve and correspondence with French workers).

${ }^{2}$ Hinton, R. J., Chapter on George Odger, in English Radical Leaders. New York, I 875 .

${ }^{3}$ Hinton was not the most reliable of chroniclers and there are numerous errors on points of fact in his book. For this reason his account of how Odger outwitted the Confederate agents should be treated with some reserve. It is, however, quite consistent with certain other facts which can be independently established. The Bee-Hive's financial difficulties were acute at this time, and they complicated the struggle over the policy to be adopted on the War. The Confederate agent, Henry Hotze, was particularly interested in influencing the newspaper press.

4 The Working Man, May \& June 1862. W. P. Wallrage on the American Labour Question. 
alliance between Bright and the British workmen. ${ }^{1}$ But it was not for nothing that Henry Adams, son of the American Ambassador in London, referred to the "patient efforts" which Beesly was obliged to make before Bright and the trades unionists could be brought together on the platform at St. James Hall. ${ }^{2}$ Thus, in December 1862 , the Rev. E. A. Verity, who had considerable claims to the regard of workmen in London and the provinces, came forward with a proposal which Beesly saw as a gambit aimed at confirming Bright in his status of persona non grata in the Labour Movement. Subsequent events proved conclusively that Verity was a Confederate sympathiser, but he won considerable support when he addressed the London trades as a representative of the Padiham Workingmen's Relief Committee and appealed for funds. ${ }^{3} \mathrm{He}$ declared that trades unionists and cooperators were being victimised by the middle-class committees in the North. His appeal met with a favourable reception among leading London workmen irrespective of their attitude to the Civil War. They had already become disgusted with the official Mansion House Relief Committee in London which had decided to invest its funds in Consols.

Beesly deplored the decision to set up an independent Workers Committee for the relief of Lancashire distress. He was persuaded that there was venom in the philanthropy of Verity and Charles Kingsley. Behind their appeals for the cotton operatives he heard the voices of the Squire, the Parson and the Slave-owner. The real objective was political: to discredit the Radical manufacturers and separate them from the workmen. He challenged Verity to give the names of manufacturers who were guilty of injustice towards workmen, but Verity declined to do so. ${ }^{4}$ Nevertheless Beesly was obliged to revise his estimate of the Northern manufacturer as....

"An honest man close buttoned to the chin,

Broadcloth without and a warm heart within."

A fellow Positivist, Dr. J. H. Bridges, who was working closely with J. R. Stephens, eventually persuaded him that the charges against some of the middle-class relief committees were well founded, and the Professor made a public admission of his error, which was charac-

1 Harrison, F. Autobiographic Memoirs, Vol. I, p. I65.

2 Glicksberg, C.I., Henry Adams Reports on a Trades Union Meeting.

New England Quarterly 1942.

3 Lancashire Distress: Middle Class Relief Committees, by "scourge". The Bee-Hive, $27^{\text {th. December } 1862 .}$

4 Verity, E. A., The Bee-Hive, 3rd. January 1863. 
teristically full and unqualified. ${ }^{1}$ However, events soon showed that his instinct in the matter had been sound, for Verity was discovered to be less than honest in money matters. By March I 863 he had been repudiated by all the London workmen except certain avowed supporters of the Confederacy and was attempting to divert attention from the charges which had been brought against him by references to "the treachery displayed towards the working classes by bringing back John Bright and the Manchester School, whose advocate he is, into the society of trade unionists. ${ }^{2}$

Virtually all the historians of the period are agreed that the meeting in St. James Hall on 26th. March I863 was "the most notable one in support of the North held throughout the whole course of the war" 3 It represented a decisive turning point in the history of the response of British workmen to the Civil War. If Odger, Howell and Cremer went to the meeting fearful that it would be a failure or in the hands of a hostile crowd, ${ }^{4}$ they left in the knowledge that the London workmen were overwhelming in support of President Lincoln and unalterably opposed to any British intervention. If George Potter tried to dissuade fellow trade unionists from going to speak at the meeting, he took care to be a member of the deputation led by Bright and Beesly which subsequently called upon the American Ambassador. ${ }^{5}$ Facey and Leno also changed boats at about this time. Potter told Ambassador Adams that "should our Government be forced into a war with America by the pressure of the Southern sympathisers in Parliament, the whole power of the masses would be brought to bear against such a war". ${ }^{6}$

Early in April i 863, the Bee-Hive declared that Southern sympathies were now confined to "a very small section among the least thinking of the working millions". 7

Nevertheless, the friends of the Confederacy in the Labour Movement were not wholly silenced nor were they deprived of their influence. The London Trades Council had come near enough to make itself responsible for the St. James Hall meeting to find itself in trouble with $\mathrm{T}$. J. Dunning of the Bookbinders and with other unions, such as the Compositors, in which Confederate sympathisers

1 Liveing, S., A. Nineteenth Century Teacher: J. H. Bridges. 1926. Beesly, E. S., Lancashire Discontent, Bee-Hive, 28th. Februaty 1863.

2 Verity, E. A., The Secularists and the East Lancashire Relief Fund, the Bee-Hive, 28th. March I 863 .

${ }^{3}$ Adams, E. D., op. cit. p. 133.

4 Hinton, R. J., op. cit.

5 Trades Union Deputation to the American Minister, Bee-Hive, 9th. May 1863.

6 Ibid.

7 Bee-Hive, i Ith. April 1863. 
might exploit the prejudice against mixing up union business with politics. Reynolds News might be embarrassed by the task of reconciling its opposition to the Federals with its own advanced democratic programme, ${ }^{1}$ but it tried to do so despite the way in which Bright and Beesly had linked support for the North with opposition to privilege at home; Emancipation with Reform; and interest in Negro rights with the international solidarity of the working class. ${ }^{2}$ In common with the Glasgow Sentinel and the Miner and Workman's Advocate, Reynolds insisted that the issue was unaltered by the Emancipation Proclamation. War against the Federals might now be dangerous and inexpedient, but that did not alter the fact that the negro's freedom in the North was more intolerable than his bondage in the South. ${ }^{3}$ Indeed, events were to show that even the BeeHive might return to its earlier pro-Southern character.

By the beginning of 1864 the realisation had come to the Confederate agents who were at work in England that "public opinion, even though but slightly represented in Parliament, was yet a powerful weapon with which to influence the Government". "In January I 864 , W. S. Lindsay described to Mason, the Confederate Commissioner, his plans for establishing a "Southern Independence Association" in London. It was decided to concentrate upon two issues. First, to stimulate anxiety about the enormous increase in emigration to the Northern States which had taken place during 1863 . Second, to exploit Palmerston's humiliation over the Schleswig-Holstein question in the hope of bringing down his Government and securing the return of the Tory party to power. ${ }^{5}$

The signal for Southern sympathisers to redouble their activities was apparently picked up very quickly in the Labour Movement. After having allowed nearly a year to elapse since the meeting in the St. James Hall, T. J. Dunning suddenly raised the matter as a serious issue, and called upon his members to sanction the disaffiliation of the Bookbinders from the London Trades Council. It is true that he coupled his protest against Unions being mixed up with the proNorthern agitation with a denunciation of political movements in general, and of Odger's "Address to the Working Men of France" in particular. But it was the Civil War which he dwelt on, and his preference for the Confederacy was not concealed. The London Trades Council, said Dunning was the nucleus for so-called political move-

1 Reynolds News, 7 th. June 1863.

2 Great Meeting of Trades Unionists, report of speeches by Bright, Beesly etc., Bee-Hive, 28 th. March 1863.

3 Reynolds News, Ioth. May \& 2nd. August 1863.

4 Adams, E. D., op. cit. Chapter XV.

5 ibid. 
ments of the working class. The meeting addressed by John Bright in St. James Hall "was taken for granted by the general public to be a demonstration of the trade unions of London... The trades were not consulted at all, much less their authority given". ${ }^{1}$

In the Bookbinders' Trade Circular Dunning announced that "the trades of London are dead against slavery, but they have no confidence in Mr. Lincoln either as an opponent to slavery or as a friend to the Negro. His Emancipation Proclamation, which extends only to the disloyal states, they consider less intended to benefit the negro, than to destroy, if possible, the 'Confederates'. Of course we say nothing as to their correctness, but such are the opinions of nine out of every ten workmen we have heard speak on the matter. Nor have we found one who can see the justice or the neutrality of one of the belligerents being allowed to obtain men, arms and ammunition from this country, while the other is not allowed to obtain ships, or able to see the legal distinction between the two, except as so much 'bosh', set up to cover the partiality or the fears of the English Government."

The meeting in St. James Hall reminded Dunning of nothing so much as the pronouncements of the Three Tailors of Tooley Street. It was said that this meeting had changed the policy of the Government. "If so, which we can hardly believe, it only shows on how utterly false a basis political events sometimes turn". ${ }^{2}$

Within his own union Dunning was able to carry all before him. The Bookbinders disaffiliated from the London Trades Council, and C. Goddard, who was their representative on that body and who had signed the Address to the Working Men of France, was absolutely discomfited. Goddard had proposed a vote of thanks to Professor Beesly for his suggestion that London trades unionists organise a pro-Federal meeting, ${ }^{3}$ but he was so intimidated by Dunning that he now denied all knowledge of the matter. ${ }^{4}$

1 Editorial Comment: The Bookbinders Trade Circular, 2 March 1864.

2 ibid.

3 Trades Intelligence, in: Bee-Hive, 28th. February 1863.

4 Report of Lodge Meeting: Bookbinders Trade circular, 2 March I 864.

Not all the Southern sympathiscrs or adherents of the "No Politics" school in the trades union movement delayed their protests about the St. James Hall meeting for as long as Dunning. Thus, "Unionist", writing in the Oldham Standard of 9th. May I 863 stated: "I cannot conceive who were the persons that attended the meeting in St. James Hall... except that they were the hirelings of a clique which is at present doing all it can to protract the war in America and cause continued stagnation and prostration of trade at home." The price of adopting Bright's advice to take part in politics would be inability "to wage any strife whatever against the capitalists in future... Thete could no longer be the unity requisite to protect the rights of labour amongst trades unionists... Some would no doubt support the North, yet there are also those who would support the South in their desire to preserve their independence." 
At exactly the same time as Dunning launched this attack, George Troup reappeared in the editorial columns of the Bee-Hive. As one would expect, the emigration question served as his theme, and he delivered a tremendous broadside under the heading: "The Price of Labour in the Colonies and the States". In this article he insisted that emigrants to the United States were being used either as cannonfodder, or as black-legs in industrial disputes. Sooner or later, these unfortunate emigrants would have to bear the awful weight of taxation which the United States Government would be bound to impose in view of the immense national debt. British workmen would be better off in the colonies than under President Lincoln, who was - according to Troup - the greatest political blunder of all time. ${ }^{1}$ Many supporters of the Bee-Hive were profoundedly dismayed to find that Troup could still have access to its editorial columns. In particular, Professor Beesly was most indignant. In the course of 1863 he had contributed nearly thirty long articles to the paper, and half of these had dealt directly with the Civil War. He never tired of insisting that the South could be subdued, and when the Confederate armies scored successes, he reminded his readers that "the insolent chuckle of the upper classes ought of itself be sufficient to stir the blood of every workman who means to stand by his order. Every blow suffered by the North is a blow to the hopes and prospects of the masses here..." 2 From Beesly's point of view, Troup's return was a betrayal of working-class interests, and he demanded that Robert Hartwell, the new editor of the paper, should give some explanation.

At first, Hartwell maintained that Troup's article had been published by mistake, ${ }^{3}$ but further contributions from the ex-editor were accepted in the name of "free discussion". Troup, closely supported by Verity, Vize and Dunning, engaged Beesly, Edmund Beales and others in prolonged controversy. They denied that they were expressing pro-Southern views; a denial which Troup qualifies by adding, "so far as they may be pro-slavery views." They chiefly insisted upon three points. First, upon the association between support for the Federals in America with support for the Manchester school at home. Beesly and Beales were accused of wanting to make the Bee-Hive "on the American question, a Manchester School and Federal paper, similar in these respects to the Morning Star". ${ }^{4}$ Second, upon the duty to

1 Troup, G. The Price of Labour in the Colonies and the States, in: Bee-Hive, 2oth. February I 864 .

${ }^{2}$ Beesly, E. S., The American War, in: Bee-Hive, 23 rd. May 1863.

${ }^{3}$ Beesly, E. S., The Working Man in America and An Editorial Explanation: Mr.

Troup and the American Question, in: Bee-Hive, 27th. February 1864.

4 Dunning, T. J., Bee-Hive, 5 th. March 1864. 
acquaint workmen with the terrible fate that awaited emigrants to the United States. Dunning tried to make his readers' flesh creep with a story about a nephew of his whom he supposed to have been kidnapped by the Federals. "It makes one's blood boil at the puny talk of the learned Professor (Beesly)...". ${ }^{1}$ Third, upon the objectionable opinions entertained by their opponents with regard to the Schleswig-Holstein question and continental politics. Some continental political issues, particularly the Polish question, cut across the American agitation rather awkwardly for Federal sympathisers. They were obliged to explain why they were opposed to intervention and war in the West, while favouring intervention - even to the point of war, - in the East. ${ }^{2}$ The fact that the United States enjoyed rather better diplomatic relations with Russia than it did with other European powers was an embarrassing complication. The Southerners could be relied upon to exploit these difficulties to the full. Similarly, they did not allow it to escape notice that Beesly, perhaps the most effective and prolific of the Federal supporters who contributed to the Bee-Hive, took up a very ambiguous position in relation to Bonapartism. ${ }^{3}$ Whether these arguments had much influence upon the London workers is very doubtful. The new generation of trade unionists were not afraid to find some merit in the Manchester School. ${ }^{4}$ They probably agreed with Beesly when he said: "So far as the Party generally known by that name desire to extend political freedom, to lighten taxation, to diminish the power of the aristocracy and to encourage the Federals in putting down the slave-holders, I sympathise with them heartily. Their opinions on industrial questions I have combatted energetically in the pages of the Bee-Hive and elsewhere; and as it is for those that it is sought to make me responsible, I must stigmatise the insinuation as disgraceful, from whatever quarter it comes". 5

However, the Federal supporters were not strong enough to drive Troup and Co. from the pages of the paper. Beesly's argument that "free discussion" could be taken too far, and that it would be as sensible to allow anti-trade union as pro-Confederate propaganda in the Bee-Hive, was not heeded. ${ }^{6}$ The Southerners suggested that

1 ibid.

2 The Independence of Poland: Great Demonstration by Members of Trade Societies, Speech by the Chairman, E. S. Beesly. Bee-Hive, 2 May 1863.

3 Beesly, E. S., Napoleon and the Congress, in: Bee-Hive, 5th. December 1863. and Napoleon and his Policy, in: Bee-Hive I 9 th. December I 863.

4 Letter "on behalf of a large body of our fellow-workmen, the friends of the Federal States of America", signed by Odger, Dell etc. Bee-Hive, I 2 th. March I 864.

${ }^{5}$ Beesly, E. S., The Colonies and the States, in: Bee-Hive, I 2th. March I 864.

6 Ibid. 
this was just the sort of point that one would expect to hear from a friend of Bonapartism. Beesly gave up in disgust and did not write another word for the paper until after the Civil War was over.

Beesly insisted that the majority of London workmen were in agreement with him. He pointed to the fact that numerous assemblies of workmen had expressed sympathy with the North, while the Southerners could organise no such meetings; he asserted that the directors of the Bee-Hive had declared Troup's views on the Civil War to be at variance with working-class opinion. ${ }^{1}$ How then was it possible for Troup and Dunning to command so much space in the paper? The answer would appear to be that while the editor was sincerely opposed to the Confederacy, George Potter, as manager, cared very little for general principles of any sort. It would have been most embarrassing for Potter to have broken completely with Troup and Dunning, since the former was the largest single share-holder in the Bee-Hive while the Bookbinders also held a considerable block of shares. ${ }^{2}$ It may be presumed that, in these circumstances, Potter thought it expedient to press for a policy of "free discussion" on the American War and that he carried the day.

One of the reasons why the history of Confederate sympathies in the Labour Movement is worth recording is that it throws some light on the origins of the famous quarrel between the Bee-Hive and the London Trades Council; the conflict between George Potter and the Junta. No doubt, the Webbs and Raymond Postgate pointed to the essential meaning of this quarrel which loomed so large in the eighteensixties, ${ }^{3}$ but they failed to notice or perceive the significance of Potter's role as accomplice with George Troup, the friend of the Confederacy. When Potter attempted to organise a meeting in memory of Abraham Lincoln, the Junta got out a handbill bitterly denouncing him, and employing against him passages from proSouthern articles which had appeared in the early numbers of the Bee-Hive. ${ }^{4}$ One of the points in the famous series of charges which George Odger brought against Potter was that he had used the BeeHive to peddle Confederate propaganda. ${ }^{5}$

The fact that the working-class press was so largely in the hands of men whose opposition to the North made them friends of the Con-

1 Ibid.

2 Trades Newspaper Company, Articles of Association and List of Shareholders. Public Records Office.

${ }^{3}$ Webb, S. \& B., History of Trade Unionism, I91 2 edition, chap. 5. Postgate, R., The Builders History, 1923. Chapters 9 and 10.

4 The Miner and Workman's Adrocate, 6th. May I 865.

5 The Bee-Hive, 24th. June 1865. 
federacy, adds to the significance of the sympathy which the majority of politically conscious workmen displayed towards Lincoln and the Union. The struggle to organise support for the North was a nursery in which to raise a new type of labour leader; a leader who had to withstand the reproaches of representatives of an older generation who suffered from fixed ideas and incorrigible prejudices.

The meeting in St. James Hall in March $186_{3}$ was not the result of some simple and spontaneous expression of the will of the entire working-class. The understanding between Bright and the organised workers - with all its positive and negative consequences for the further progress of the Labour Movement - did not spring painlessly, uncaused out of the head of time. Isolation of the working-class from general political movements, and the rule that trades unions should take no part in politics were traditions which had to be courageously challenged before the Reform agitation could develop. The struggle alongside Bright during the American War and the combatting of the Southern sympathisers within the Labour Movement made an important contribution to the growth of an esprit de corps among the members of the Junta, and helped to create the condition for its subsequent dominance. In defiance of Dunning, Reynolds, Stephens and the rest, W. R. Cremer used the meeting with Bright on 26th. March I 863 to make a pledge that old differences should now die and that they would work together for Reform. "Now we believe trade unionists, from their business habits and organisations fitting them for united action, peculiarly adapted for working out the enfranchisement of the masses." When the cause of Reform had triumphed, Howell observed to John Bright: "Your presence with us on the American question... gave a great impetus to the political tendencies of the Unions, and aided us greatly in our endeavours to being them into the political arena". 2

${ }^{1}$ Bright-Cremer correspondence, Bee-Hive, 2oth. June 1863.

${ }^{2}$ George Howell to John Bright, 7th. October I 867 . Bishopsgate Institute. 